\title{
Education and National Politics in Chuvashia (1960-2014)
}

\author{
Erbina Nikitina, Vitaliy Stanyal, Gennadiy Trifonov \\ Philosophy Department, Chuvash State University, Cheboksary, Chuvash Republic, Russia \\ Email: gen-trifonov@yandex.ru
}

Received 5 February 2015; accepted 30 March 2015; published 2 April 2015

Copyright @ 2015 by authors and Scientific Research Publishing Inc.

This work is licensed under the Creative Commons Attribution International License (CC BY). http://creativecommons.org/licenses/by/4.0/

(c) (i) Open Access

\section{Abstract}

In the review written in the form of answers to questions from the expert group of UNESCO headed by IoannaKucuradi, dr. ph., the general contours of educational process in the Chuvash Republic are described on the basis of statistical and sociological data. The authors conclude that Chuvashia occupies an unstable intermediate position between two estimations: on the one hand, balanced situation in the sphere of culture of interethnic relations and support of humanistic development of the person in the system of education, and on the other hand, social and economic backlog of the region, belittling of the role of regional components of education, language, literature, culture, which negatively influences the status and quality of ethnonational school. National school in the Chuvash Republic doesn't exist in its full sense. Strengthening of an ethnoregional component in school and high school education of Chuvashia is explained by the growth of national consciousness of the people, ethnopolitical transformations in the country and support by the federal centre of researches on ethnoproblematics. Among actual problems in the system of education of the Republic one can mark the absence of demand for experts with higher education on labour market, low level of wages of experts, high rate of unemployment among youth, discrepancy between the educational structure of graduates and the structure of available vacancies, necessity of strengthening of connection between vocational training and labour market. It's established that the ethnic aspect of existence of multiethnic population of Chuvashiya is not the ground for violence and terrorism as the humanity and tolerance principles lay at the heart of the Chuvash ethnomentality, and the main values of the Chuvash ethnopedagogics are peace, work, honour and equality of all people.

\section{Keywords}

Education System of the Chuvash Republic, National Politics of the Chuvash Republic, Interethnic Relations, Ethno-Regional Component in Education, National School 


\section{Introduction}

The Chuvash people are an ancient and uniquely viable nation. Twice-in the VI century in Asia and in the XIII century on the Volga - "a red cow (war) ate the book" and left the ethnos without history and state. Today the Chuvash Republic is also a unique member of the Russian Federation, in which the national trait "aptramanlykh" (stamina) surviving in a remarkable manner specifies the whole living environment of the Chuvash people.

At the beginning of 1960/61 academic year 199.9 thousand students studied in 1067 general education schools (291 primary schools, 397 eight-year schools, 168 secondary schools, 204 schools for working and rural youth, a correspondence school for adults and 6 schools for children with special needs). In 2011/12 academic year 125,921 students studied in 481 day general education schools, 11 evening schools, 17 special general education schools.

The number of urban and rural vocational training colleges grew up to 17 by 1965 . In 2012 the number of elementary vocational institutions remained the same-17. 7766 students studied in 20 specialized secondary schools.

In 1965/66 academic year 10.4 thousand students studied in 3 higher education institutions. In 1967 I.N. Ulyanov Chuvash State University was opened. By 2012 there were 24 higher vocational institutions (5 independent higher education institutions and 17 branches).

By 2012 there remained 435 pre-school education institutions, half as many as before (399 nurseries and 36 school-nurseries). In 20 boarding-schools and 3 orphanages over 3 thousand children are being reared, half of them are orphaned children. 2 thousand of adopted children and 2360 fosterlings are nurtured in the families of the citizenry.

Such is the system and dynamics of functioning of the Chuvash Republic's schools. Massive reports (up to 200 pages) are issued annually by the Ministry of Education and Youth Policy of the Chuvash Republic.

In our answers to the questions proposed to us by the expert group of UNESCO headed by Ph.D., Professor, Honorary President of the International Federation of Philosophical Societies, Joanna Kuçuradi we will touch only some "pressure points" of pedagogic and educational system of the Chuvash Republic.

Tragic historical events, poor economic and social development of the region determined the low living standards of the Chuvash people over the course of the past millennium. Nevertheless, lacking spacious fields and strategic underground resources, in the Soviet period the Republic successfully developed large industry of federal and universal importance (hop-growing, hog farming, poultry breeding, electric accessories, mechanic engineering, cotton manufactory). But reversion to wild capitalism in the 1990s dramatically changed social and industrial pattern, threw masses of the population decades back to poverty.

According to the results of 2006, Chuvashia ranked 78 in average monthly money income, 79 in scale of pension, 74 in nominal wages, 63 in gross regional product per capita. In 2007 Chuvashia ranked 68 in unemployment. Collective farms, guilds, state farms and large enterprises are ruined under the slogan of privatization. Under the pretense of optimization and modernization hundreds of rural schools, art schools, music schools, nurseries are closed down. G.S. Lebedev Chuvash National Lyceum, I.N. Ulyanov Chuvash State University Preparatory School, Yadrin National Gymnasium, Republican boarding school, Art center in Kuvshinka, Centers of artists and writers in Cheboksary were shut down.

Despite this, Chuvashia is the republic where upward trend of human development remains (rank 33). As the authors of the program "Social and cultural evolution of Russia and its regions" note, "The Chuvash Republic shows medium sustainable uplift which is achieved by the benefits of humanitarian parameters and takes up the middle ground among the regions of Russia" [1].

In volume of accommodation commissioning per head the republic ranked 4, in road construction and gas infrastructure development it excelled not only in the Volga Federal District, but also in Russia.

Official media can justify the authorities and find many reasons for praise. "The effort of the Republican Government over the last 15 years is aimed at development of human capital assets, consequently, at education and public health service development, as well as all social infrastructure of the region (accommodation, roads, energy supply, etc.). Republican power (President N.V. Fyodorov's governance is meant) is an efficient factor commencing social-economic and innovative processes. It set rather ambitious tasks aimed to turn the Republic to one of the most dynamic regions and propel it to European level of development” [2].

Unfortunately, these ambitious tasks are still far from implementation. By 2014 unemployment hasn't been extirpated, accommodation availability is low. There are hundreds of children in wait for nurseries, although 
over the last years the Head of the Republic M.V. Ignatyev has been strenuously handling this problem, year by year opening more than a dozen of nurseries. By this factor Chuvashia is rated among ten best regions of Russia.

\section{What Are the Prime Factors That Have Led to the Growth of Racism and Other Forms of Discrimination in Chuvashia during the Last 50 Years?}

There is no racism problem in Chuvashia. We can emphasize the absence of interethnic problems and burst of nationalism in the region. For ages the Chuvash set of mind and ethnic religion has been advocating "the equality of all peoples under the moon and the sun". Among the regions of Russia national republics of the Volga region and Cisurals (Chuvashia, Mari-El, Mordovia, Udmurtia, Bashkortostan) refer to the groups of the least risk in terms of ethnic and racial discrimination.

However, the existence of dozens of indigenous peoples as members of the Russian State, unique interrelations of its multilingual and multi-confessional nationals had always been a stumbling block for the monarchy and the Holy Synod of the Russian Empire, for the political nomenclature of the Soviet Union, and remains topical for the Government of the modern Russian Federation. The problems connected with interethnic relations, national characters, ethnical stereotypes of behaviour and mentality of the Russian peoples have been influencing the State Policy, including educational one.

Because of impairment of the members of national minority rights, political tension and lawsuits originate now and then. Insults of Russian highest ranks against "nationhood" of the national members, bilingualism in the titular republics, pressure on ethnic religions and other facts, such as promotion of the slogan "Russia for the Russians" or "Mononational' Russia”, always discontent the ethnoses. It's necessary to mention that the President of the Russian Federation V.V. Putin in his latest articles and Address to the Federal Assembly took into account the factor of ethnic mentalities and understood the necessity of multiple citizenship building on the ground of polyethnicity of the country. The Government's support of positive interrelations of ethnic mentalities, citizenship and legitimacy on the vast asymmetrically polyethnic area of Russia began to be reflected at once on solving of practical problems of transition of the society to a democratic social-legal state.

But the marks of ethnic discrimination on the part of Federal Government are routinely observed in the regions. At the turn of the 1980-1990s the ethnical patriotism not evaluated by rights and named by the accusatory nickname "nationalism", became one of the reasons of collapse of the USSR. Collapse of the Soviet Union illustrated dramatically the power and depth of ethnical identity and ethnical mentality. In the XXI century each of the peoples of Russia and the CIS continued searches for original, ethically imbued fate with renewed vigour.

However, in present-day Russia not belonging to Russian-speaking nation means in practical terms diverse launch opportunities and diverse resources for the development of ethnic culture, media, school and individual career realization. Division of the peoples of Russia into "great nations" and "ethnic minorities", unequal distribution of wealth and resources fall short of standards of civil society and discourage equal development of the ethnoses.

As envisioned by Russian statesmen, democracy in Russia must eliminate ethnic peculiarities. Such problem statement aggravates the question of value of national cultures, traditions and languages.

Ethnic mental characteristics of many peoples of Russia (e.g. the Tatars, Bashkirian, Chuvashes, Buryats, Kalmyks, Balkars, Chechens, Ingush) disagree with the European classic concept of citizenship. Rough correcting, violent deformation of mentalities of the peoples of Russia through the media, education, upbringing lead to negativism, grading of ethnic, spiritual, cultural peculiarities of the population, without which the ethnoses transform into a faceless crowd. The results of school and institutional reforms of the last decades demonstrate the low level of graduates' knowledge and their high civil immaturity and social inactivity.

The peoples of Russia can't and won't sacrifice their ethnic mentality, spirituality, culture, language hard won for centuries and preserved in incredible anguishes for the benefit of proclamation of trendy profits and rather doubtful "equality of individual rights". Every Chuvash knows since childhood that "if Chuvash perishes, the world will perish". The Volga and Caucasus peoples keep in mind their communal, civil "veche” forms of government of their native land and can defend their congeners.

In modern Russia "higher-ups" are prospering and "masses" are trudging along, the super-rich oligarchal and poor working parts of the population withdraw on standard of living. As a matter of course an ordinary person opts not for quasi-civil values thrusted by force, but prefers ethnic traditions, because ethnic affiliation doesn't depend on their social standing or material welfare and in the most difficult times saves from death and cachexy. 
Ethnic linguistic discrimination runs on. It manifests itself in impossibility of social functioning of the native language. At schools the class hours designated for Chuvash philology are shortened in favour of the disciplines "Physical Education" and "Basics of Orthodoxy", Chuvash textbooks haven't been republished for decades.

Language politics in the Chuvash Republic was built on the ground of the act "About the languages in the Chuvash Republic" (adopted October 27, 1990). New statutory wordings abridging the rights of the Chuvash language - the most important marker uniting the ethnos - have appeared. This is the answer of the Republican Government to including the Chuvash language by UNESCO experts into the group of endangered languages.

There is no actual bilingualism in the Republic. In practice on the territory of Chuvashia the Chuvash language hasn't got official standing and doesn't actualize its functions. The Chuvash language, being the mother tongue of the absolute majority of the Republic's population, due to lack of distinct national policy of the Government and proselytism of the Ministry of Education is intensely losing authority in the younger generation.

The survey data acknowledge a good reason behind the worry of the researchers, cultural workers, teachers and parents concerning actual use of the Chuvash language. The language preservation problem in other regions where the Chuvash people live is one of the topics of discussion among artistic intelligentsia, activists of the Chuvash National Congress, the Counsel of Chuvash Patriarchs, Chuvash Folk Academy of sciences and Arts. About half of the ethnos lives in Chuvashia, the other half-in many regions and republics of the country, densely -in Tatarstan, Bashkortostan, the Ulyanovsk, Samara, Tyumen Regions, in Siberia. The problem is critical. For example, in the Samara Region during the time of Perestroika the number of Chuvash schools was forcedly reduced from 140 to 60 .

It's worth noting that preservation and development of the language directly depends on its teaching at schools and higher education institutions, and the policy of public authorities. Closing of the only one lyceum for gifted children and the faculties of Chuvash philology at universities, unjustified changes in orthographic rules, endless criticism of the teachers of Chuvash philology and culture, show trials of journalists-defenders of the mother tongue speak in their own right about the situation in the Republic and tar many other positive strivings of the government.

\section{What Are the Main Factors That Have Led to the Growth of Dogmatism in Its Various Forms during the Last 50 Years?}

Bureaucrats at all times and in all places resisted freethinking and are naturally attached to dogmatism. The totalitarian Bolshevist country forgetting Lenin's precepts which defended a labour man, for long postwar years had been living up to strict instructions and Gosplan. The leaders-Leninists' pupils governing the country at the end of the XX century, had never laid eyes on Lenin's "Philosophical writings". They were taught by the rest of the world to hate working Russia. It was advantageous for greedy leaders to devaluate human values-duty, responsibility, conscientiousness, industry, devotion for the benefit of the native land. Therefore, the ruling Bolshevist party was infamously wrecked by their grandsons and deservedly got into the black list of history.

There is no reason to speak about some other forms of dogmatism in Russian reality. The country has been and still is in a bustle and will strive for the recovery of national justice. The Chuvash people have an aggravate sense of equality and righteousness which is the main impediment of dogmatism expansion in the Republic.

The remaining in the Chuvash people in the XXI century way of thinking of members of national minority, i.e. non-Russian peoples being of secondary importance in comparison with the Russians which small peoples formed in the time of the Russian Empire, can be considered conservative and dogmatic. Not better was the status of "the younger brother" beside "the elder brother" in the USSR. Although the peoples' friendship was declared at the educational, cultural and informational level, the national distinctive character of the regions, differences in traditions and customs were overlaid by voluntary political ideology. Ethnic mentality as manifestation of nationalism was harshly suppressed. Russification of the peoples in czarist days, "socialist internationalism" in the Soviet times and the modern slogan "For the united Russian nation" without any doubt should be considered as the examples of negative typification of the peoples of Russia.

Among the Turkomen and Finno-Ugric people of Russia it is still characteristic for the Chuvash people to have the lowest self-esteem. There are some reasons for that. Compare: in the XIII century the ancestors of the Chuvash people at swords and guns lost runic writing system and the state of Volga Bulgaria, under the banners of Pugachev in the XVIII century they could not defend their religious originality and national names, leading forefathers in the 1920s wrongly refused from Lenin's project of "Great Chuvashia” (Chuvashstan), and now the 
Republic's leaders are standing embarrassedly at the parting of history. But in the republics of Islamic order (Tatarstan and Bashkortostan) and Finno-Ugric group (Mari El, Mordovia, Komi, Udmurtia) the other attitude of mind — brave and positive — was formed in the years of Perestroika.

Ethnic nihilism (neglect of native history and culture, traditions and customs, feeling of ethnic inferiority, deprivation, shame for the representatives of the native ethnos) is observed among the Chuvash youth, mostly in the regional centres and cities. At a time when the majority of the population including intellectuals is ethnically indifferent, ethnonihilism of the youth doesn't decrease but intensifies antiethnic activity of the Governing bodies.

\section{What Are the Main Factors That Have Led to the Growth of Poverty and Social Injustice in Chuvashia during the Last 50 Years?}

Poverty in Russia and Chuvashia in the second half of the XX century is certainly the result of the postwar total devastation. In the years of the Second World War more than 208 thousand natives of the Chuvash Republic fought at the front against fascist occupants. Over half of them didn't return home. All the forces of the Republic - till the last sack of bread and the last rouble - were given to the front line.

During the Second World War 20 enterprises were relocated into Chuvashia from the western and central regions of the country. Teenagers and young women were working heroically and without complaint on many machines in the rain and snow. This is the mentality of the Chuvash people.

In the 1950-1980s the average annual rates of growth of the total output of industry in Chuvashia outrun the all-Russian. From the agrarian republic Chuvashia became industrial-agrarian. By 197026 large manufacturing outfits had been built and brought into being, among them a cotton integrated plant, works of electric actuators, electro-measuring instruments, trac duplicates, "Chuvashkabel" in Cheboksary, "Electropribor" and "Electroautomat" in Alatyr, works of electric lift trucks, paint and varnish and plastic articles in Kanash. In 1970 the construction of Cheboksary hydro-electric power station began, in 1972-a works of industrial tractors was built. Novocheboksarsk chemical integrated plant started working.

Intensive growth of industry and liquidation of "futureless" villages led to significant migration of the population to the towns. This narrowed the number of the Chuvash language speakers and Chuvash culture-bearers. From the beginning of the 1960s at the suggestion of N.S. Khrushchev, the General Secretary of the Central Committee of the Communist Party of the USSR, the Republic's schools came over to teaching in the Russian language. The Chuvash language was driven out completely from the schools of the capital regions and towns. An abrupt withdrawal of the native language from the process of education led to the loss of the fundamentals of literacy and national traditions by the majority of its speakers. The Chuvash diaspora's schools and teachers were hard put to it.

From 1991 the decline in production has begun. Failed attempts of economy reforming, transition to the wild market led the country to crisis. Chuvashia which doesn't possess natural resources and large extractive enterprises was on a knife edge. Metropolitan oligarchs robbed the country and left the people with nothing. After the Great Patriotic War this was the second wave of complete impoverishment of the working class.

In the difficult years of market-oriented reforms the Republic's Government (as opposed to Tatarstan and Bashkortostan) couldn't preserve the attained living standards and human potential. Turbulent reformation of administration management apparatus, education systems, public health service, economic management which has been carried out during the last 15 years by the Republic's forces with federal support didn't bring any significant relief to the population. However, V.V. Putin called Chuvashia together with the Belgorod region the leader in realization of national projects among the regions of Russia. So, not only we got on ill.

In Chuvashia the income level of the population as well as the salary remain below the mean Russian values.

\section{What Are the Main Factors Which Have Led to the Growth of Violence and Terrorism in Chuvashia during the Last 50 Years?}

The Chuvash Republic is qualified as the most undangerous region of Russia. It weathered post-Soviet burden of lawlessness and banditism worthily and without big losses. The growth of terrorism in Chuvashia is not noted. The Chuvash people are tolerant and patient as no other nation in the world. The fundamental truth "it's pointless to spit against the wind" is put in their mentality.

But this doesn't mean that the people are satisfied with their standing. There have been injustices that should 
be repaired. For example, ethnic religion is completely forbidden in Chuvashia. The results of the research of Chuvash favourings and prayers were published after censorship in the corrupted form. Under the guise of reregistration the Chuvash religious community was closed. The oldest magazine "Yalav" ("Banner") was eliminated. There's no place for dialogue in the official media. Chuvash national radio doesn't go on the air in Cheboksary. The slightest comments towards the Government or constructive-critical declarations in the opposition press are certainly attributed to extremism and subjected to persecution.

Nobody is still protected in Russia from the self-will of the courts, bureaucrats, newly rich, criminality and poverty. Corruption, crime and mafia run the show. "What clapped in Moscow today, will rumble in Cheboksary tomorrow", the Chuvash people say.

It's significant that in the Republic together with stabilization of economy and sociopolitical life the lowering of negative developments is observed. The Government of the new Head of the Republic M.V. Ignatyev follows the voice of the people. For instance, in 2013 he succeeded in peaceful resolving the city square conflict which emerged around the Presidium and Executive Committee of the Chuvash National Congress.

Experience has shown that the ethnic aspect of the existence of the multinational population of Chuvashia isn't the ground for violence and terrorism. At the heart of the Chuvash world view is the principle of humanity. Traditional learnings advocate peace and labour, honour and equality. For example, goodwill to cross marriages is the indicator of ethnic paradigms and value systems of the Chuvash people towards other nations.

There is no question of Chuvash terrorism. Aggressive problem solution, descent upon the enemy, elimination of the offender is not customary for the Chuvash people. In the Chuvash justice there's a relict phenomenon "tipshar", an act of suicide as the form of punishment of the offender. The word "tip" is explained from the Arabic "tebb"-perish, doom; consequently. "Tipshar" is an "insuperable misfortune".

Chuvash "tipshar" is commited when a person injured or insulted innocently wants to prove their guiltlessness and sees that the society doesn't respond to their arguments, but the offender escapes punishment by hook or by crook. "Tipshar" can't be considered as the sign of powerlessness and humility, compliance with injustice. Chances are that it's proving one's right or a mute outcry, an individual verdict to an abjurer or a criminal who doesn't want to bear responsibility for acts or neglects someone else's fate on account of their inaccessibility on the part of the law or impossibility of the proof of their guilt. According to the Chuvash religion "sardash", the war of nerves due to "tipshar" is more prominent than the burden of imprisonment or corporal punishment.

In the XXI century "tipshar" in its pure form is rare among the Chuvash people, but in teenagers and men of middle years the display of "tipshar" with sociopolitical motivations occurs time after time. In the 2000s the public acts of self-burning on the central squares of Cheboksary and Moscow were committed by a businessman, a law enforcement officer, a leader of Chernobyl cleanup veterans.

As distinct from many regions, any national-chauvinistic, anti-Semitic phenomena are not observed in the Republic. The Chuvash national movement tends to decide concrete national-cultural and educational problems instead of satisfying political or international ambitions.

Terrorism can be introduced to the Chuvash Republic only from the outside. The events of the 1990s connected with the holding of the first conference of the Chuvash National Congress, the organization of the Union of Regional Ethnographers, adoptions of the law "About languages in the Chuvash Republic" and elections of the first President of the Republic, have shown that in Chuvashia there are some concerned forces artificially enkindling group and ethnic conflicts.

Constant growth of inflation, unstable funding of budgetary institutions and organizations, criminalization and corruption, privatization of markets and farm markets by migrants, dramatic growth of gap in the standard of life of different social groups of the population, perceptible economic lag of the Chuvash Republic from a number of the neighbouring republics and regions affect the people's mood, and this can become a reason of the national protest.

Multi-ethnicity of the society is wrongly perceived by many as the main source of tension and conflicts. On the contrary, the ethnoses united by the territory, way of life and historical destiny, possess necessary objective and subjective conditions for comprehensive cooperation, mutual aid and understanding.

Social behaviour of a person is typified; it conforms to the norms developed by the society. Behavioural standards are transformed being unified under the influence of the information on history and culture of the neighbouring people. In the multi-ethic Volga Region ethnopolitical situation is calm because historical co-residence of the ethnoses with different mentalities and cultural traditions is perceived as a natural valuation.

Socio-political factor has a stronger effect on stability and tolerance of behaviour of the peoples. For example, 
the Chuvash people, the Mari, the Mordovians, the Udmurt and other members of national minority are unpretentious, diligent, obedient, tolerant because for eight centuries of colonial slavery and official low language the non-Russian people in the Russian state have formed the new mentality, the new instinct for self-preservation without maximalism, extremism, on the basis of constant, laborious, fanatical creation instead of destruction. The oppressed mood and dependent position of the people merged with national character and identical forms of self-defence.

For the moment the situation is complicated by the central authorities' attack on the status of the ethnic regions. The national republics in accordance with the Federal Constitution are the sovereign states having their own constitutions, legislation, state emblems, and territory. That is to say, a national republic is a state within the Federation. In the Constitution of the Chuvash Republic [3] adopted by the State Council of the Chuvash Republic on November 30, 2000, in item 1 of article 1 of chapter 1 "Foundations of the constitutional order of the Chuvash Republic" it is said: "The Chuvash Republic-Chuvashia is the Republic (state) within the Russian Federation". In item 1 of article 6 it is noticed, that "the Chuvash Republic bears liability for preservation and development of culture of the Chuvash people and promotes development of culture of all people living in the Republic”. Thus, the Chuvash people which received their nationhood were declared the nation, i.e. historically highest type of ethnos which is characterized by the unity of the territory, economic life, culture and national consciousness.

The existence of the nationhood, common language and culture, own territory is an indispensable sign of the nation. The indigenous peoples of the national republics are reasonably called the title nations. However, the word "state" was excepted by the Law of the Chuvash Republic from May 24, 2012 No. 37 item 1 of article 1 of the Constitution of the Chuvash Republic. Now Chuvashia is just a republic. There are no prizes for guessing what consequences this political decision will have for the Chuvash people. The society and a part of the deputy corps are indignant by "the chaos in the State Council" and voice their protest [4]. In the 1990s the Chuvash National Congress disagreed with the withdrawal of the entry "nationality" from passports, in 2013 it pronounced a special decision with the requirement to restore the definition of nationhood in the Constitution of the Chuvash Republic. The advance of the Federal Government on the small ethnoses, on their conventional sovereignty seems an eccentric trick of the big brother in relation to the younger ones.

Thus, "in modern Russia the threat to socio-political stability is constituted not by inter-ethnic conflicts, but by growing socio-political tension as the direct consequence of xenophobia expansion and growing discrimination of minorities”, O.A. Litsenberger [5] acknowledges.

\section{What Is the Role of Education (Elementary, Secondary and Higher School) in the Growth of the Phenomena Mentioned Above?}

Russian and Soviet pedagogy including Chuvash one have never and in no way served the purposes of discrimination, racism, violence, terrorism. For the older generation in Chuvashia this problem is difficult to understand. Probably, teenagers and young people stuffed with severe plots of news and TVseries through the mass-media understand it better.

The sphere of education in the Republic provides availability of free education for all social groups. Much attention is given to children crime prevention. Elaborate national policy in the sphere of education is pursued; the manifesto "Strategy of development of education in the Chuvash Republic till 2040" is approved.

Absence of demand for higher education professionals at the labour-market, low wages of experts, high unemployment among the youth, discrepancy between educational structure of graduates and structure of available vacancies, necessity of strengthening of connection between vocational training and labour market remain actual in the Republic, as well as in a number of other regions.

The number of school children wishing to go into further academic study at the 10-11 forms of the secondary school is growing; the number of schools with possibilities of differential training and preparation for the future profession has increased, as well as the number of schools with studying of new subjects of humanitarian cycle (law, ecology, consumer education, economy, etc.). The number of students in secondary and higher vocational training institutions is growing-by 1998 it amounted to 237 students per 10 thousand population. This exceeded the all-Russian indicator (197). Educational institutions of a conceptually new type-gymnasiums, lyceums - are opened. The interest to Chuvash culture, history, language has raised. The new required special fields in higher education institutions are being opened. 
However, many points of the republican program "New school” (1997) remain non-realized due to lack of material and financial support.

As the results of the Unified National Exam show, the qualitative development of rural schools still lags behind the urban ones. The main reason is ungradeness, deficiency of training methods, insufficiency of manuals and absence of academic performance rating in the regional courses. Nevertheless it spelt out that "one of the ways of improvement of quality and efficiency of educational process at rural school, and of its scientificallymethodical support is the deepening of national traditions in the content of education, more active involving of school children into the native ethnocultural environment, guarantee of the native language proficiency" [6].

The situation of gradual estrangement of the population from the native language has been formed. Since September 1, 1995 the classes were given in the Chuvash language for 31626 school children $(14.4 \%$ of the total number), in the Tatar language-for 1832 people (0.8\%). In 6 years 22446 school children (11.2\%) were taught in the Chuvash language, in the Tatar language-1682 people (0.8\%). Training at schools in the Chuvash language was provided from 1 to 5 classes in all subjects; in Tatar language-from 1 to 9 classes. Now the situation has changed. As the ethnoteacher G.N. Volkov considered, "national school remained on Soviet-communistic model... we have primary Chuvash school, and later our school is not national and inferior" [7]. Nowadays training and education in the native language remained neither in nurseries, nor in elementary school.

Moreover, it is necessary to take into account that modern children and teenagers are the generation of active Internet users. School children and students receive much of educational and social information from the Internet. The people which do not have an ethnic segment in their national language in the "world wide web" automatically obtain in the eyes of the web community (which is almost equivalent to the world community) the status of ethnic groups futureless in economic, political, administrative and even the military sphere and isolated from cultural influences and results of scientific inquiry of more developed neighbours.

If we mention the problem of creation of national domains of the people of Russia, "chuvashization" of computer networks goes in very slow rates. The Constitution of the Chuvash Republic in the Chuvash language from the official site of Chuvashia is typed by "home-made” fonts and consequently can't be read. The official contract on keyboard layout pattern for the Chuvash language has not been accepted up to now. The Chuvash branch of Wikipedia opened in 2004 has only 46 active participants and about 15,000 articles. At that rate the prospects of influence of information revolution on the development of ethnic components of the Chuvash culture and formation are insignificant...

It's gratifying to emphasize that available and free primary, main and general secondary education, elementary vocational education, and also on a competitive basis free secondary vocational education, higher vocational education and postgraduate vocational education is guaranteed to each citizen.

In the middle and senior ranking of the system of general secondary education $98 \%$ of teachers have higher education; about $67 \%$ of teachers have qualification grades. Now they are occasionally gladdened with pay awards. At schools and higher education institutions there are hundreds of innovations, continuous transformations, perfections, updatings, but the quality of knowledge of school children and students catastrophically swoops down. School is a part of the society, and it cannot be other than the society itself.

Young and talented professionals with higher education are leaving for the capital cities (Moscow, St. Petersburg) and currently (thanks to the intense studying of the English language at schools of the Republic) they are leaving abroad (particularly, for the USA) because of impossibility of application of their knowledge at the enterprises and organizations of the Republic and the low salary in the sphere of intellectual activity. Many of them do not return home. The Ministry of Education and Youth Policy of the Chuvash Republic does not keep in touch with them; unfortunately, they are not taken into account while working with national personnel.

\section{What Are the Ideas Underlying This Education?}

The conception of the state educational policy of the Chuvash Republic "Man and Education in the Modern World" (adopted by the Cabinet of Ministers of the Chuvash Republic in 1998) represents the system of contemporary ideas, principles and priorities in matters of education and upbringing of the younger generation and forms the basis of the activity of the public authorities and the local Government on solving strategic problems of education.

The purpose of the educational policy is the creation of the system which develops a free, educated, cultivated Individual capable of self-fulfilment according to the demands of the changing society. 
The strategic problems of the conception are: socialization of educational institutions of all levels; formation of the person-focused content of education; optimization and rationalization of the network of educational institutions; creation of the regional system of continuous education on the basis of continuity and integration; creation of the new financial and economic mechanism of the system activity; worldwide development of national school; promotion of competitiveness of domestic labour at the local and international labour markets.

Fundamental values of the educational system: the rights and dignity of the individual;

Universal human values; historical and cultural values of Russia and Chuvashia; national consciousness; physical and moral health.

Principles of functioning of the educational system: democratization; humanization and humanitarization; variability and differentiation; scientific character and continuity; continuality and consistency; consideration of ethnocultural peculiarities of the peoples of the Chuvash Republic; evolutive innovative character.

Administration of educational environment of the Republic is exercised through purpose-oriented Government programmes "Rural school”, "Education and health of children”, "Vocational training”, "Children of Chuvashia”.

Profound changes in the society of late years were dramatically reflected upon school. In the course of endless reforms in education many positive things have been made, as well as the negative ones. Not without reason on August 23, 2011 in the report at the traditional August conference of teachers the Minister of Education and the Youth Policy of the Chuvash Republic V.N. Ivanov recollected traditions: "Our major principle is by strengthening traditions and developing innovations”.

\section{What Is the Place of the Humanities, Philosophy, Ethics and Human Rights in the Existing Educational System of Chuvashia?}

At the end of the XX century momentous decisions were made for the purposes of humanization of school education. Higher education institutions are purposefully certified, programmes and state standards of secondary school are updated; the disciplines of ethics, aesthetics, culturology, political science, sociology, jurisprudence, religious studies are introduced. The imbalance is obtained due to the cutting of the volume of the belles-lettres classics and the reduction of hours of the Chuvash literature at schools of the region.

Scientists took notice of their peoples' philosophical views. In the course schedule of philosophy in I.N. Ulyanov Chuvash State University the section "History of ethnic philosophy" is completed by the theme "The development of philosophical thought of the peoples of the Volga region and Cisurals". Intensification of the ethnoregional component is caused by the growth of national consciousness of the small peoples, ethnopolitical transformations and support of the Federal Centre of Researches on Ethnoproblematics. The school of ethnic philosophy established by the outstanding scientist, Doctor of Philosophy, Professor E.Z. Feizov (1928-2011) successfully functions at the Chuvash University. In 2010 the large International research and practice conference "Methodological problems of ethnophilosophy" (the coordinator Doctor of Philosophy, Professor V.A. Fedotov) was run in Cheboksary. It united scientists from St. Petersburg, Moscow, Rostov-on-Don, Samara, Kazan, Yoshkar-Ola, Saransk, Saratov and other cities.

Amidst the accelerating process of globalization not only in the sphere of economics and politics, but also in the field of culture and education, in the conditions of amplifying "westernization” of the Russian way of life, the interest to the problem of the ethnic mentality, traditional national values, centuries-old spiritual and moral experience of the ethnoses, national philosophy has been steadily increasing.

The aspiration of any ethnos to learn its history, preserve its culture and habitual life-supporting psychological set is natural. If in a human life the comprehension of belonging to a certain ethnos (that is to say, national consciousness or ethnic identity), searches for specific values of the nation are of paramount importance and have a serious effect on human relations (from interpersonal to interstate), then advancement of the sciences analyzing national problems from different perspectives (ethnopsychology, ethnopedagogics, ethnosociology, ethnopolitical science, ethnophilosophy), and also knowing of them in higher and secondary school are certainly necessary.

The creative work of prominent thinkers of the Chuvash people of the XVIII-XX centuries (E.I. Rozhansky, N.Ya. Bichurin, S.M. Mikhailov, M.F. Fyodorov, I.Ya. Yakovlev, N.V. Nikolsky, D.P. Yuman, G.I. Komissarov, etc.) is featured in school textbooks. The philosophical views of outstanding writers (K.V. Ivanov, M.K. Sespel, P.P. Huzangay, J.G. Uhsay, G.N. Aygi; S.V. Elger, N.F. Ilbek, F.E. Uyar, A.S. Artemyev, Yu.I.Skvortsov), artists (A.A. Kokel, Yu.A.Zaytsev, PraskiVitti, V.I. Ageev, F.I. Madurov) and scientists (M.F. Fyodorov, A.I. Petrukhin, 
G.N. Volkov, E.Z. Feizov, N.A. Ismukov, A.A. Trofimov, A.K. Salmin, M.R. Fedotov, N.I. Egorov) are set forth in high school textbooks on Chuvash literature and national culture.

The upper-form pupils and students favourably conceived the list of report themes. Many reports on ethnic culture and ethnic philosophy of the Chuvash people got prize-winning places at the international and regional youth conferences. Here is the approximate list of the themes:

1) The problem of national consciousness in national philosophical idea.

2) Ethnis religions of the people of the Volga region and Cisurals.

3) The general and special in the mentality of the Russian and Chuvash (Tatar, Mari, etc.) people.

4) The enlightener of the peoples of the Volga region I.Ya. Yakovlev about "the Chuvash nature".

5) The problem of spiritual and state revival and development of the peoples of the Volga region in the artistic legacy of the Chuvash thinkers G.I. Komissarov (Vander) and N.V. Nikolsky.

6) The philosophy of "aptranmalykh" (stamina of the Chuvash people) in P.P. Huzangay and A.P. Huzangay's creative works.

7) "The Earth Philosophy" in the epic poetry of the national poet of Chuvashia J.G. Uhsay.

8) Philosophical and aesthetic views of the Chuvash poet G.N. Aygi.

9) The language role in the formation of national consciousness (on the ground of the works of N.N. Poppe, M.R. Fedotov, etc.).

10) The problem of death and immortality of man. The Japanese "harakiri”, the Chuvash "tipshar”, etc.

\section{Are There Any Positive Changes Which Bring Hope for Future?}

Pendency and aggravation of social and economic, national, cultural and everyday problems in the conditions of weakening of ideological and state dictation in the late 1980s promoted the origin of the social movements supporting expansion of the rights of the republics and peoples. In 1988 the Main Board of the Chuvash Elders set to work in the new format. At the end of 1989 the Chuvash Social and Cultural Centre was set up. In 1991 the Party of the Chuvash National Revival was formed. In 1992 the Chuvash National Congress was established, its delegates represented the Chuvash population of the Republic and the Chuvash diaspora. Positively stabilizing results of these organizations are evident.

The commitment of the Chuvash youth to healthy family life still remains; women as before take the responsibility for prosperity of their home and family. Natural tolerance of the Chuvash people, aspiration to accuracy and decency did not disappear, despite wild laws of the market. The national orientation "Don't get so far ahead of the others, don't go behind the people” contradicting the capitalist criteria, still works.

The developed sense of patriotism, congeners' credibility, recognition of equality of all before the law, adherence to traditions, non-contentiousness and peacefulness - these core mental qualities of the Chuvash people almost have not changed, and this should answer for fulfilment of positive aspirations of the nation.

Despite strong negative influence of antiethnic and unprincipled television and Internet on the processes of urbanization and population flow that has intensified lately, the Chuvash people abroad and in the other regions of Russia maintain links to relatives and business contacts with the Chuvash land, don't lose spiritual ground, remain faithful to the beginnings and origins of their people, bonds of their home ground.

The Internet gives a chance to Diasporas to nestle to native culture and native language through the sites opened in national languages by the enthusiasts of ethnic culture, the Internet version of national print media and online broadcasting of national television and radio companies. For example, in the Chuvash world N. Plotnikov's site "Chavashkhalaknsayche" (the Chuvash National Site), the Chuvash online newspaper "Ireklesamakh" (the Free Word) and the National radio of Chuvashia in the online mode are much sought after. Under the influence of information revolution the traditional elements of culture are modernized, gradually penetrating into the "world wide web" and showing considerable adaptable potential to technological innovations.

Here's joyful news opening the Internet prospects for the Chuvash people-the social network "Vkontakte" has at last been translated into the Chuvash language! From the birth of this idea till its embodiment some years have passed. One can turn on the interface in Chuvash by switching to the tab "Options", then choosing the point "Chavashla" in the section "Regional options".

The similar facts bring hope to believe, that Chuvash people "were at Adam, are and will be till the end of the world”. 


\section{Conclusions}

In virtue of many tragic events the history and culture of the Chuvash people are dusted in the haze of millennia. The whole layers of unstudied ancient riches are housed in oral and written arts of the people. But the poor Republic isn't in the mood for cultural wealth, and for the Russian Government the Chuvash people have only been the silent members of national minority, "weeds on Russian field" as N.A. Polevoy, the author of "the History of the Russian people”, writer publisher and historian claimed...

Even a brief research of the region on the basis of statistical and sociological data allows getting ambiguous educational portrait of the Chuvash Republic. Chuvashia occupies intermediate position between two estimations. On the one hand, the Republic is balanced by the law, humanistic development of the person is supported on many aspects. In this context a lot of worthy affairs are made.

On the other hand, the region is functionally oppressed; the equality of the ordinary worker and the representatives of the higher class, the equality of ethnoses in the conditions of federalism, are only pronounced. At social disbalance any human and civil rights abuse causes discontent. And this is the indicator of reaction of the people, theirs viability, activity and desire to create and develop.

For prosperity of Chuvashia the authorities should listen to opinion of the general population and to satisfy some requirements scanty for the state, but essential for the ethnos.

\section{References}

[1] Lapin, N.I. and Belyaeva, L.A., Eds. (2009) Regions in Russia: Social and Cultural Portraits of the Regions in AllRussian Context. Academia, Moscow, 658-667.

[2] Boyko, I.I., Kharitonova, V.G. and Shabunin, D.M., Eds. (2011) The Chuvash Republic. Social and Cultural Portrait. Chuvash State Institute of the Humanities, Cheboksary, 183.

[3] The Constitution of the Chuvash Republic (2011) Chuvash Publishing House, Cheboksary, 5.

[4] Maksimov, N. (2013) Opposition Fights with Chaos in the State Council. Just Russia-Chuvashia, 6 April, 1-2.

[5] Litsenberger, O.A. (2011) Perception by the Government of Ethnic Cultural and Religious Self-Expression. Reporter of the Russian nation, 4-5, 232-241.

[6] Presidential Programme “New School”-In Development (1998) National School, 2, 33-39.

[7] Moiseev, P.V. and Nikitina, E.V. (2002) The Nation Will Preserve Itself by Its National School (Interview with G.N. Volkov). National School, 5, 6-10. 